\title{
Factors of Developing International Retail Chain Brands in the Regions of the Russian Federation
}

Anna Mikhailovna Chernysheva, ${ }^{+*}$ Alexandra Alexandrovna Trofimova, $^{\dagger}$ Valentina Viktorovna

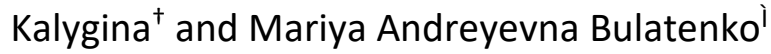

\section{Abstract}

The development of international and local (federal) retail chains is significant for the development of the country's economy in the modern context. It can be stated that the problems of the retail chain development are reviewed in applied aspects more successfully than in theoretical aspects, which reinforces their urgency. This article is devoted to the factors of international retail chain development in Russia by regions, including Moscow and St. Petersburg. The authors cite the development of outlet centres in the Russian regions and the quality of retail space as factors with a considerably e influence on the international retail chain development. The developers' task is to intensively develop the construction of outlet centres in cities with a million-plus population, ensuring that retail chains, primarily international ones, become anchor tenants. The reason is that anchor tenants become centres of attraction that provide rental of retail space (usually from $5 \%$ to $15 \%$ of the total area of the outlet centre) and offer a wide range of goods to the outlet centre visitors at attractive prices. The purpose of this article is to study the factors of international retail chain brand development in the regions of the Russian Federation and to establish a connection between the opening of outlet centres and the development of global retail chains. To this end, the statistical data presented in the JLL 2015 Report and official statements of authorised representatives and agencies regarding the development of retail chains were analysed. It is suggested that a close relationship between the opening of outlet centres and the development of international retail chains in the regions of the Russian Federation will be established during the analysis, including the classification of cities for the development of global retail chains due to the effect of various factors.

Keywords: International Retail Chains, Federal Retail Chains, Retailers, Outlet Centres, Retail Floors, Street Retail, Mass Market, Developer.

\footnotetext{
† People's Friendship University of Russia (RUDN University), 117198, Miklukho-Maklay Street, 6, Moscow, Russian Federation

*Corresponding Author, Email: chernysheva-am@rudn.university

' Moscow Power Engineering Institute, 111250, Krasnokazarmennaya Street, 14, Moscow, Russian Federation

C2019 Chernysheva et al.. This is an Open Access article distributed under the terms of the Creative Commons Attribution License (http://creativecommons.org/licenses/by/2.0), which permits unrestricted use, distribution, and reproduction in any medium, provided the original work is properly cited.
} 


\section{Introduction}

It has been observed that for 250 global retail companies, there was an increase in revenue by $4.1 \%$ which amounted to $\$ 4.4$ trillion. These are the US retail chains - such as Wal-Mart Stores ( $\$ 485.9 \mathrm{bln})$, Costco Wholesale ( $\$ 118.7 \mathrm{bln})$, and The Kroger Co ( $\$ 115.3 \mathrm{bln})$, which continue to dominate in the global retail chains. There are also Russian companies in this list - for example, the Russian retail chain Magnit is on the 57th line and leads the list of retail chains. Some other retail chains include Lenta, Dixy, and X5 Retail in the list (Deloitte, 2018).

It must be noted that the retail chains selling consumer goods occupy the top lines of the ranking. At the same time, the retail chains selling clothes and accessories do not hold leading positions despite being highly profitable segments.

European retail chains (82 companies are represented in the Global Powers of Retailing 2018 ranking) most actively expand to the markets of other countries, receiving $41 \%$ of total revenues. Such information leads to the conclusion that international retail chains are striving to develop both within and beyond the national market, seeking for favourable conditions.

The Russian market is one of the capacious markets for international retail chain development. According to research conducted by the Retail and Loyalty Journal (Retail \& Loyalty, 2017), retail sales volumes stabilised in April 2017 after the fall by $4.6 \%$ in 2016 . At the same time, retail trade turnover has been increasing since May 2017 - for example; it has observed an increase of 3\% in 2018 (Press Release, 2018). As such, the Russian market is attractive for international retail chains again, having escaped from a protracted economic crisis.

The increase in the average spend of the Russians confirms this estimate (it amounted to 543 rubles in November 2017). At the same time, its growth was observed in all districts of the Russian Federation, except for the Volga and
North-West districts. In total, the overall increase in the average spend was ensured by the residents of cities with one-million and halfmillion population. Consequently, the trends include the increase in sales channels through the development of the presence of retail chains in the regions of the Russian Federation.

The retail trade sector accounted for $17 \%$ of Russia's GDP in 2017 (Press Release, 2018), where the food retail chain is represented mostly by Russian companies, and European companies mainly represent the non-food sector.

As such, the issues of identifying the critical factors of the development of international retail chain brands in the regions of the Russian Federation become relevant. Their development, along with the development of federal chains, exacerbates the struggle between them and regional chains. Meanwhile, international and federal chains have such competitive advantages as the sale of specific product categories are $30-40 \%$ cheaper due to their volumes and ability to open their outlets both in outlet centres and in standalone stores in the streets.

The issues of international and federal retail chain development, as well as the determination of the effect of development factors have a prominent place in marketing management, since the retail chain expansion has an impact on the economic condition of the country in general, which is covered in the works of E.V. Matuzenko (Matuzenko \& Gorelova, 2014). The development of retail chains in the country and their impact on the economy are covered in the works of both domestic (Leonov \& Burmistrov, 2012; Fligstein, 2013; Akhmedzyanova, 2014; Chernysheva et al., 2017) and foreign scientists (Hannan \& Freeman, 2004; Gilbert, 2005). The features of operation and management of retail chains - both international and federal - were covered in the works of such scientists as V.P. Cheglov (2016), V.A. Lazarev (Lazarev \& Yakushev, 2012); crisis management of chain development was covered in the works of Zh.V. Gornostayeva (Bekker \& Gornostayeva, 2011) 
and G.V. Mikheev (Mikheev \& Derkacheva, 2016). The issues of the development and operation of retail chains are covered by such scientists as L. Dolega (Dolega et al., 2016), T.J. Richards (Richards et al., 2018), K. Picot-Coupey (Picot-Coupey et al., 2018). This research, however, aims to probe the indicators of developing retail chain brands in regions of the Russian Federation. The next section sets the contextual framework of the research.

\section{Problem Setting}

International and federal retail chains are the key protagonists of this research. The international retail chains include companies that have opened a store in the Russian Federation under a global brand present in two or more countries. Federal retail chains are companies from the Russian Federation that have opened stores under a Russian brand in more than three federal districts of Russia and develop mostly in the domestic and CIS markets.

International retailers from about 26 countries are represented in the Russian Federation, most of these chains (80\%) have come to Russia from Europe - primarily, from Italy and France, which account for $30 \%$ and $15 \%$, respectively. The UK and Germany occupy the third and fourth lines with $10 \%$ and $9 \%$. The US accounts for $10 \%$ (JLL, 2015). International and federal chains are represented in such categories as Clothing, Shoes, Household Appliances and Electronics, Cosmetics and Perfumery, Accessories, and Other. The Other category includes household goods, luxury and premium, etc.

Such international chains primarily represent Italy as Max Mara (luxury segment), Calzedonia, and the United Colors of Benetton (mass market segment). France is represented mainly on the retailers market in the luxury segment by such brands as Cartier, Christian Dior and Louis Vuitton, as well as a leader of the retail cosmetics industry - Yves Rocher. Retailers from the US dominate both in the luxury segment (GUESS and Calvin Klein) and in the fast food segment (SUBWAY, KFC, and McDonald's). The most widely represented brands in the cities under study were Adidas, Yves Rocher, Calzedonia, ECCO, Reebok, United Colors of
Benetton, Reserved, and SUBWAY (Press Release, 2018). Among other things, the active presence of these retailers is due to franchising. It must be noted that retailers develop most intensively in places where outlet centres are present. The street retail format is less preferred, which is a significant obstacle in the retail chain development.

Amongst the cities of Russian Federation, Moscow is the leader of the international and federal chain presence, accounting accordingly for $97 \%$ and $93 \%$. St. Petersburg (56\% and $79 \%$ ) and Yekaterinburg (40\% and $75 \%$ ) are also in the top three (JLL, 2015). Outsiders of the international chain presence are Astrakhan, Naberezhnye Chelny, Ulyanovsk and Penza, and outsiders of the federal chain presence are Khabarovsk, Ulyanovsk and Vladivostok. At the same time, there is a broader presence of federal chains in the regions than international ones. This situation is primarily due to the uncertainty and caution of international chains, as well as the quality of retail space in the regions of the Russian Federation. At the same time, the latter factor plays a key role. For example, Krasnodar and Voronezh are not cities with a million-plus population, but they overtook cities with a larger population only due to the availability of highquality retail floors.

Overall, the international retail chains have largely penetrated the regions in the Urals and Volga districts. However, $24 \%$ are present only in Moscow (mostly luxury and premium segment). Distribution of federal retail chains is evener. International chains are better represented in the Clothing profile (40\%), Luxury and Premium (37\%), and Shoes (8\%). Federal chains are described by the largest representation in the Clothing (63\%), Other (13\%), and Shoe categories (12\%) (JLL, 2015).

Figure 1 demonstrates the dynamics of retail trade turnover and its growth rates in the Russian Federation. As can be seen from the chart, the retail trade turnover was declining with the growth rate of retail sales during the crisis periods. However, there is an increase in these indicators at the moment that restores pre-crisis indicators, which indicates that the 


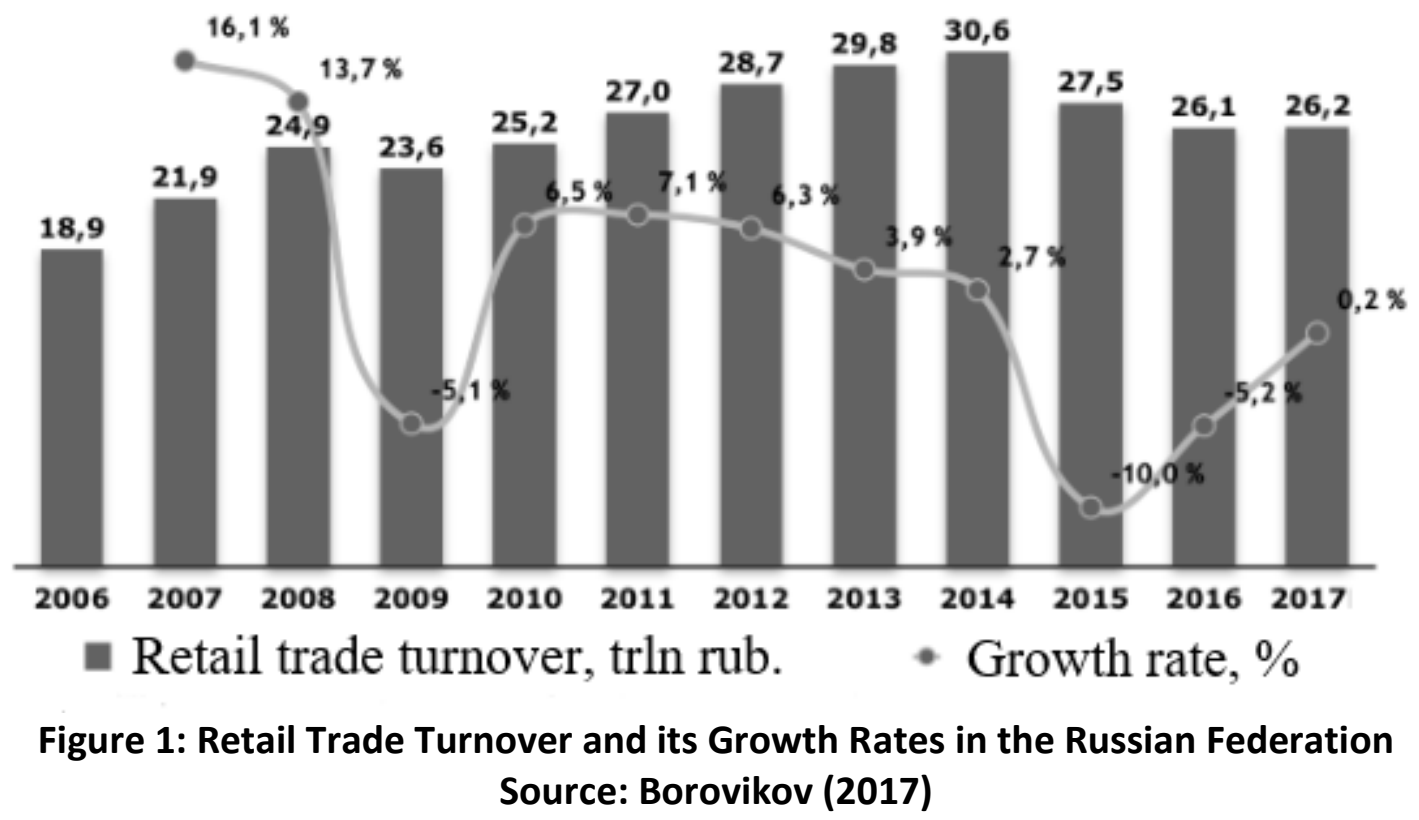

market is sufficiently attractive for international retail chain brand

\section{Methods}

At the heart of this research is to probe the indicators responsible for the development of international retail chain brands in the regions of the Russian Federation. Hence, to define the impact of the quality of retail space, the largest cities of the Russian Federation were selected with a significant presence of international retail chain brands and the appropriate number of outlet centres by population density using 20152016 data. In this case, the presence of an international retail chain brand is marked, if there is a mono-brand store or a franchise/subfranchise store on the market. The data presented in Table 1 defines the impact degree and the tightness of the relationship between the presence of international retail chain brands and the number of outlet centres (quality of retail space) in the regions of the Russian Federation.
Based on these data, the regression equation $\left(y_{x}=a_{0}+a_{1} x\right)$ will be as follows:

$$
\begin{aligned}
& \mathrm{a}_{0}=\frac{\sum \mathrm{y} \sum \mathrm{x}^{2}-\sum \mathrm{yx} \sum \mathrm{x}}{\mathrm{n} \sum \mathrm{x}^{2}-\sum \mathrm{x} \sum \mathrm{x}} \\
& \mathrm{a}_{1}=\frac{\mathrm{n} \sum \mathrm{yx}-\sum \mathrm{x} \sum \mathrm{y}}{\mathrm{n} \sum \mathrm{x}^{2}-\sum \mathrm{x} \sum \mathrm{x}} \\
& \mathrm{a}_{0}=0.09428 \\
& \mathrm{a}_{1}=0.00321 \\
& \mathrm{y}_{\mathrm{x}}=\mathrm{a}_{0}+\mathrm{a}_{1} \mathrm{x}=0.09428+0.00321 \mathrm{x}
\end{aligned}
$$

Parameter $a_{1}$ is called the regression coefficient and indicates the change in the resultant attribute when the factor sign changes by one, which means that the share of international retail chains increases by $0.3 \%$ as the number of outlet centres increases by one. Parameter $a_{0}>0$, which allows concluding that the share of international retail chains changes more slowly than the change in the emergence of outlet centres in the city. 


\begin{tabular}{|c|c|c|c|c|c|c|}
\hline City & $\begin{array}{l}\text { City ranking by } \\
\text { the number of } \\
\text { international } \\
\text { chains }\end{array}$ & $\begin{array}{l}\text { Number of } \\
\text { outlet } \\
\text { centers (x) }\end{array}$ & $\begin{array}{l}\text { Share of international } \\
\text { chains present in the } \\
\text { city to the total } \\
\text { number of chains } \\
\text { present in the Russian } \\
\text { Federation (y) }\end{array}$ & $x y$ & $x^{2}$ & $y^{2}$ \\
\hline Moscow & 1 & 298 & 0.97 & 289.06 & 88,804 & 0.9409 \\
\hline St. Petersburg & 2 & 81 & 0.56 & 45.36 & 6,561 & 0.3136 \\
\hline Yekaterinburg & 3 & 23 & 0.41 & 9.43 & 529 & 0.1681 \\
\hline Rostov-on-Don & 4 & 9 & 0.3 & 2.7 & 81 & 0.09 \\
\hline Krasnodar & 5 & 18 & 0.3 & 5.4 & 324 & 0.09 \\
\hline Kazan & 6 & 16 & 0.25 & 4 & 256 & 0.0625 \\
\hline Nizhny Novgorod & 7 & 23 & 0.24 & 5.52 & 529 & 0.0576 \\
\hline Novosibirsk & 8 & 14 & 0.23 & 3.22 & 196 & 0.0529 \\
\hline Samara & 9 & 13 & 0.21 & 2.73 & 169 & 0.0441 \\
\hline Voronezh & 10 & 11 & 0.17 & 1.87 & 121 & 0.0289 \\
\hline Omsk & 11 & 11 & 0.16 & 1.76 & 121 & 0.0256 \\
\hline Perm & 12 & 9 & 0.16 & 1.44 & 81 & 0.0256 \\
\hline Krasnoyarsk & 13 & 10 & 0.14 & 1.4 & 100 & 0.0196 \\
\hline Chelyabinsk & 14 & 18 & 0.14 & 2.52 & 324 & 0.0196 \\
\hline Ufa & 15 & 13 & 0.13 & 1.69 & 169 & 0.0169 \\
\hline Tyumen & 16 & 14 & 0.12 & 1.68 & 196 & 0.0144 \\
\hline Volgograd & 17 & 6 & 0.11 & 0.66 & 36 & 0.0121 \\
\hline Saratov & 18 & 14 & 0.09 & 1.26 & 196 & 0.0081 \\
\hline Vladivostok & 19 & 6 & 0.09 & 0.54 & 36 & 0.0081 \\
\hline Tolyatti & 20 & 8 & 0.09 & 0.72 & 64 & 0.0081 \\
\hline Orenburg & 21 & 5 & 0.09 & 0.45 & 25 & 0.0081 \\
\hline Irkutsk & 22 & 8 & 0.07 & 0.56 & 64 & 0.0049 \\
\hline Khabarovsk & 23 & 4 & 0.07 & 0.28 & 16 & 0.0049 \\
\hline Tomsk & 24 & 9 & 0.06 & 0.54 & 81 & 0.0036 \\
\hline Izhevsk & 25 & 8 & 0.06 & 0.48 & 64 & 0.0036 \\
\hline Ryazan & 26 & 12 & 0.06 & 0.72 & 144 & 0.0036 \\
\hline Kemerovo & 27 & 10 & 0.05 & 0.5 & 100 & 0.0025 \\
\hline Yaroslavl & 28 & 10 & 0.05 & 0.5 & 100 & 0.0025 \\
\hline Barnaul & 29 & 6 & 0.04 & 0.24 & 36 & 0.0016 \\
\hline Novokuznetsk & 30 & 1 & 0.04 & 0.04 & 1 & 0.0016 \\
\hline Lipetsk & 31 & 5 & 0.04 & 0.2 & 25 & 0.0016 \\
\hline Penza & 32 & 7 & 0.03 & 0.21 & 49 & 0.0009 \\
\hline Ulyanovsk & 33 & 10 & 0.03 & 0.3 & 100 & 0.0009 \\
\hline $\begin{array}{l}\text { Naberezhnye } \\
\text { Chelny }\end{array}$ & 34 & 7 & 0.03 & 0.21 & 49 & 0.0009 \\
\hline Astrakhan & 35 & 6 & 0.03 & 0.18 & 36 & 0.0009 \\
\hline Total & - & 723 & 5.62 & 388.37 & 99,783 & 2.039 \\
\hline
\end{tabular}

Source: Calculated by the Authors based on JLL, 2015; RBC Research, 2015; Malls.ru, n. d.

The calculation of the linear correlation coefficient allows judging about the tightness of the connection between the presence of outlet centres and the emergence of international chains.

$$
\begin{aligned}
& r=\frac{\sum x y-\frac{\sum x \sum y}{n}}{\sqrt{\left(\sum x^{2}-\frac{\left(\sum x\right)^{2}}{n}\right) \times\left(\sum y^{2}-\frac{\left(\sum y\right)^{2}}{n}\right)}} \\
& r=0.88
\end{aligned}
$$

Since the linear correlation coefficient is positive, a direct relationship between the 
attributes can be observed, and its location in the range from 0.7 to 0.9 indicates a high relationship between them.

The coefficient of determination $\left(r^{2}\right)$ is 0.7744 . This means that $77.44 \%$ of the deviation in the emergence of international retail chains can be explained by the presence of retail space in the city, and the remaining $22.56 \%$ can be attributed to the impact of other factors. The following sections critically discuss the findings of the research.

\section{Results}

Entry of international chains into the market of the city is closely connected with the opening of outlet centres. The Methods section presents a correlation between the share of the presence of international retail chain brands and the number of outlet centres in some cities. In this case, outlet centres can provide international chains with high-quality retail floors that meet their requirements. However, this is not the only factor determining the choice of a city for the presence of an international chain. For example, logistics, among other things, belong to this group of factors.

The above-analysed cities, except for Moscow and St. Petersburg, can be conditionally divided into four groups. Group A includes cities (Yekaterinburg, Krasnodar, etc.) with the most developed markets and sufficient population with high incomes, which are large industrial centres with a strong economy, high level of retail space and high sales rates. These figures are indicators for retail chains, mostly international, for their entry into the market. Group B (Voronezh, Novosibirsk, etc.) has a slightly smaller capacity of the retail market and about $300 \mathrm{sq} \mathrm{m}$ of high-quality retail space per thousand people, and there should be a positive trend in household incomes and retail turnover. The third group, C (Perm, Volgograd, etc.), has a low volume of high-quality retail space, low turnover, but at the same time, they have a potential of income and retail floors growth. Group D (Lipetsk, Khabarovsk, etc.) is currently at the emerging stage, with low income of population and little presence of retailers due to the small amount of retail space.

Overall, the estimation of the correlation between the presence of a sufficient amount of high-quality outlet centres and the presence of retailers allows us to conclude that the opening of an outlet centre is a key factor for retail chains, especially international ones, to enter the market of the city. At the same time, the construction of outlet centres depends on the population and their incomes. Major outlet centres in the Russian Federation do not form anchor tenants only from international or regional chains. At the same time, the most interesting cities for international retail chain brands when entering the market are cities with a million-plus population.

As such, on the one hand, the international retail chain brands should develop in the markets of Russian regions, because they demonstrate stabilisation and slight growth after the crisis (Figure 2).

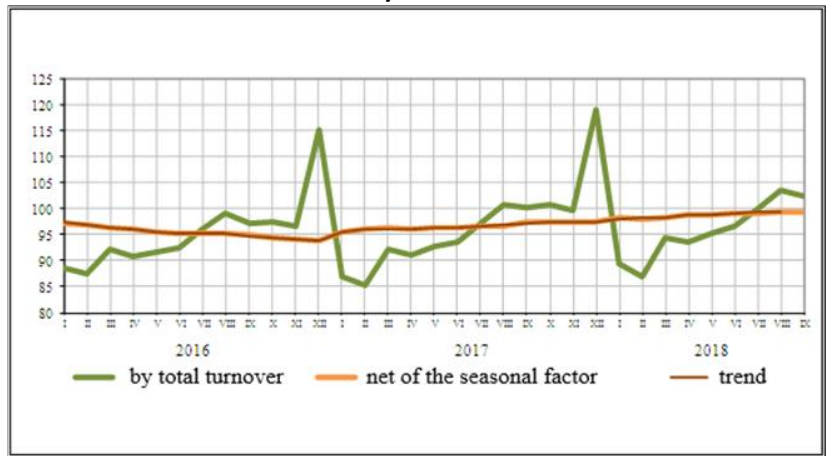

Figure 2: Dynamics of Retail Turnover (in\% to the 2015 monthly average). Data Net of Seasonal and Calendar Factors were estimated using software DEMETRA 2.2. As new data of Statistical Observations Emerge, the Dynamics can be Updated Source: Federal State Statistics Service (2018) 
On the other hand, Russian regions are also interested in the development of international retail chains, which in turn might encourage the development of the region, and therefore, must develop high-quality retail floors.

\section{Discussion}

The entry of international retail chain brands into the market is accompanied by direct investment, which is an essential aspect for the development of regions. However, it also causes opposition from national retail chains. For example, the national retail chain Lotus (Thailand) borrowed specific organisational innovations from Wal-Mart as a countermeasure but was subsequently acquired by the international retail chain Tesco.

If a national retail chain has a significant market scale, it can withstand the expansion of international retail chains. For example, national retail chains D\&S and Cencosud (groceries) and Sodimac (household products) in Chile have resisted the expansion of global brands such as Ahold, Carrefour and Home Depot. This was due to the inability of global brands to achieve a certain scale and understand the institutional and social constraints of the country of expansion, as well as competitive advantages of the national chain. The same reasons forced such brands as Carrefour and Wal-Mart to quit South Korea, while Tesco managed to fit its activities in the framework of the country, primarily due to the intensive and tight cooperation with Samsung.

Local authorities often restrain international retail chains' development. They provide preferential access to capital for national chains since global brands can get cheaper international loans or apply to investment funds.

The practice of establishing a joint venture also takes place - for example, in Brazil, where the national retail chain CBD merged with the French retail chain Casino.

As it turned out earlier, it is essential for international brands to have high-quality retail space. For example, global brands face stiffer competition in countries where street trading is very popular. As such, the establishment of joint ventures becomes popular in penetration to the national market. An interesting example in this context would be the interaction of the international retail chain Tesco, which intensively cooperates with CP Group in Thailand, Samsung in South Korea, Sime Darby in Malaysia, and Ting Hsin in China.

As such, it can be concluded that the international retail chain development forces national chains to copy international experience and secure support from local authorities. This expansion also contributes to the transnationalisation and consolidation of the country's retail market.

The dynamics of the declining market that occurred in 2014 can be considered as an opportunity opened by cheaper rent, which can be seen from the development of retailers in such segments as food, mass-market clothing, and children's products. An 18-fold increase in retail space in the Russian Federation over the past decade is another positive trend for the development of federal and international retail chains. Outlet centres seek to increase attendance by concentrating a wide range of tenants (both anchor and regular) on their retail space, including entertaining events, cafes, restaurants, etc.

However, some negative factors prevent the entry of global brands. They are:

- shortage of high-quality retail space in the regions of the Russian Federation, except for cities from group $A$,

- lack of logistic and road infrastructure, which entails longer delivery time and transport costs,

- more rigid work schedule as contrary to the European standards, where stores are open six days a week,

- wide range of national chains,

- complexity of interaction with Russian suppliers, which often allow undersupply, errors in batching, etc.,

- forced outsourcing of some services from the countries of residence of international retail chains,

- low level of nonfood retail consolidation, and 
- Moscow is usually the starting point for international retail chains to enter the market of the Russian Federation.

The entry of international retail chains in the regions of Russia and their development is determined by globalisation, which can be represented as franchising, licensing, concession, joint venture, acquisition and/or organic growth.

Correspondingly, global brands have some advantages that contribute to the development and retention of their positions in the markets:

- long-term experience in various national markets and the global market,

- a fine-tuned system of operation of the retail chain in general,

- well-regulated procurement system for a wide range of goods, which reduces the risk of undersupply and allow to reduce price with a large turnover,

- the possibility of obtaining low prices from suppliers in exchange for the presence of their products on the shelves of an international retail chain, and

- availability of sufficient free financial resources.

Overall, the size and concentration of the retail chain is a prerequisite for its entry into the foreign market, while the availability of highquality retail floors allows the international brand to settle on the chosen market firmly. At the same time, some global brands use a franchise, which will enable them to reduce risks while increasing their presence in the market.

\section{Conclusion}

The modern context of economic development in the Russian Federation observes stabilisation and even a slight increase in retail turnover, as well as an increase in the construction of highquality retail space in the regions of the Russian Federation. As such, favourable conditions are formed for the entry and development of international retail chains. Moscow ranks third in Europe after London and Paris by the presence of international retail chains, which value the prospects for the development in the Russian market. At the same time, Moscow and St.
Petersburg has the most high-quality retail floors and positive dynamics of the population and its incomes.

Classification of cities by groups presented in the Discussion section allows international retail chains to define the most promising regions for their opening and development in the Russian Federation. Consequently, high-quality retail space, primarily large outlet centres, should be built in order to attract global brands as anchor tenants, inter alia.

Based on the data provided in the Methods section, the key factors for the international retail chain development in the regions of the Russian Federation are the availability of highquality retail space in the city and the population with access to an outlet centre, mall, hypermarket, or another modern format. This is why most international retail chains are present in Moscow, St. Petersburg, Yekaterinburg, Chelyabinsk, Kazan, etc.

Following the above analysis, it can be concluded that the stabilisation of economic phenomena and processes in Russia contributes to the entry of international retail chains into the market. In this case, cities with high-quality retail space and sufficient market capacity will be predominant regions of entry. The international retail chain development entails the development of the general economy of the region, which means that gradual saturation of the cities of the Russian Federation with high-quality retail space can be expected.

\section{References}

Akhmedzyanova, R.V. (2014). International experience in the development of retail chains. Bulletin of Tyumen State University: SocioEconomic and Legal Research, 8, 85-92.

Bekker, E.I., \& Gornostaeva, Zh.V. (2011). Development of retail chains in the Russian Federation. Business in Law, 6, 175-178.

Borovikov, M. (2017). FMCG-2017: Market dynamics, player plans and key trends. Retrieved November 24, 2018 from https://rb.ru/opinion/trends-fmcg/. 
Cheglov, V.P. (2016). Integration of trade in Russia: Theory and practice. Moscow: Prospect. Chernysheva, A.M., Kalygina, V.V., Kosyakov, M.A., \& Mareeva, M.A. (2016). Optimization of the sales plan of the industrial enterprise in market conditions. Journal of Advanced Research in Law and Economics, 7(1), 32-39.

Deloitte. (2018). Global Powers of Retailing 2018. Retrieved November 24, 2018 from https://www2.deloitte.com/content/dam/Deloi tte/global/Documents/consumer-industrialproducts/cip-2018-global-powers-retailing.pdf.

Dolega, L., Pavlis, M., \& Singleton, A. (2016). Estimating attractiveness, hierarchy and catchment area extents for a national set of retail centre agglomerations. Journal of Retailing and Consumer Services, 28, 78-90.

Federal State Statistics Service. (2018). Dynamics of retail trade turnover of food products, including drinks, and tobacco products, non-food products. Retrieved November 24, 2018 from

http://www.gks.ru/free_doc/2018/b18_01/mak -rozn.htm.

Fligstein, N. (2013). Market Architecture: Economic Sociology of Capitalist Societies of the 21st Century. Economic Sociology, 3(14), 64-95.

Gilbert, D. (2005). Retail Marketing Management. Moscow: INFRA-M.

Hannan, M, \& Freeman, J. (2004). The population ecology of organizations. Bulletin of St. Petersburg University: Management, 3, 5183.

JLL. (2015). Destination Russia 2015. Analysis of the presence of 250 federal and international brands in the main cities of Russia. Retrieved November 24, 2018 from http://www.jll.ru/russia/ruru/\%D0\%B8\%D1\%81\%D1\%81\%D0\%BB\%D0\%B5 \%D0\%B4\%D0\%BE\%D0\%B2\%D0\%B0\%D0\%BD\%D 0\%B8\%D1\%8F/178/destination-russia-2015.

Lazarev, V.A., \& Yakushev, D.S. (2012).

Classification features of local retailers.

Retrieved November 24, 2018 from http://uecs.ru/logistika/item/1120-2012-03-1206-11-05.
Leonov, D.I., \& Burmistrov, M.B. (2012).

Problems and opportunities of own trademarks of retail networks in Russia. Brand management magazine, 1, 18-38.

Malls.ru. (n. d.). Retrieved November 24, 2018 from http://www.malls.ru.

Matuzenko, E.V., \& Gorelova, I.E. (2014). Current trends in the development of retail chains. Bulletin of Belgorod University of Cooperation, Economics and Law, 4, 115-120.

Mikheev, G.V., \& Derkacheva, E.A. (2016). FMCG sector: Management of development and marketing adaptation. Scientific works of KubGTU, 13, 179-192.

Picot-Coupey, K., Viviani, J.-L., \& Amadieu, P. (2018). Determinants of retail store network expansion via shop-in-shops. International Journal of Retail \& Distribution Management, 46(10), 915-943.

Press Release. (2018). Overview and development prospects of the Russian retail market in 2018-2019: purchasing power is declining, foreign networks are losing the market. Retrieved November 24, 2018 from http://www.press-

release.ru/branches/markets/obzor_i_perspekti vy_razvitiya_rossiyskogo_rynka_roznitsy_v_201 8_2019_pokupatelnaya_sposobnost_snizha_10 _10_2018_15_05/.

RBC Research. (2015). Retail chains selling food and related products (FMCG) in Russia 2015.

Retrieved November 24, 2018 from http://alfabank.rbc.ru/media/research/file/FMC G_\%D1\%81\%D0\%BF\%D0\%B5\%D1\%86\%D0\%B2 \%D0\%B5\%D1\%80\%D1\%81\%D0\%B8\%D1\%8F.pdf

Retail \& Loyalty. (2017). Russian retail in 2017: The long-awaited "thaw" after a long winter. Retrieved November 24, 2018 from https://www.retail-loyalty.org/news/rossiyskiyriteyl-v-2017-godu-dolgozhdannaya-ottepelposle-dolgoy-zimy/.

Richards, T.J., Hamilton, S.F., \& Yonezawa, K. (2018). Retail Market Power in a Shopping Basket Model of Supermarket Competition. Journal of Retailing, 94(3), 328-34. 